caro's studies on the Gracchan period, consisting in a collection of the fragments of the orators of that epoch, together with a running commentary. This will be found valuable on account of the fulness of its references to the sources, ancient and modern; we are glad to note that the author shows a thorough familiarity with the work of English scholars-Greenidge, Underhill (whose name, however, he almost always aspirates), Warde Fowler, etc. This article is followed by an essay by $\mathrm{E}$. Ciaceri on the trials of Gabinius and Rabirius Postumus in B.C. 54 . Without adding much to our knowledge, the author puts certain matters in fresh lights; he is, for example, inclined to take a more favourable view of Gabinius than that conventionally adopted by those who follow Cicero in all things. He accepts Dessau's arguments as proving that Rabirius Postumus is to be identified with the 'Curtius' or ' Postumus' of Cicero's later correspondence, from which it follows that Rabirius secured a seat in the Senate and even had aspirations after the consulship under the Caesarian régime; and he rightly points out that this does not necessarily imply-what has been assumed in consequence-that Cicero's speech in his behalf secured a verdict in his favour, for the trial was not (strictly speaking) a criminal one, involving exile as the normal consequence of condemnation, but a suit for recovery of monies under the quo ea pecunia pervenerit clause of the Lex Julia de Repetundis.

Amongst the other contents of the volume mention may be made of Ettore Pais' article on Fundi, a cogent plea for the excavation of the site, and an examination of the names given to Western peoples in the Old Testament by Oberziner.

\section{H. Stuart-Jones.}

\title{
CORRESPONDENCE
}

To the Editors of THE Classical Review.

I AM much obliged to $\mathrm{Mr}$. Sloman for correcting my mistake as to the manuscript reading in Ovid, Ars am. III. 758. I am sorry that through pure carelessness I did him a slight injustice.

As to my appeal to Plautus I should like to say a few words. In our elementary books we naturally keep for the sake of simplicity and consistency to the Latin of a certain period. But it sometimes happens that we want a word or a form for which we cannot find evidence in the writers of that period. What is the best course to follow in such a case? Take, for instance, this interesting verb edo. It cannot be ignored, and yet, when we come to set out its forms, we cannot find authority for them all in the writers of the Golden Age. Some of the 'irregular' forms (e.g. esse, est, esset) occur quite frequently enough in prose and poetry of various kinds to show that they were in general use, and we have no evidence that 'regular' forms such as edere were beginning to supplant them.1 But it so happens that the Imperative does not occur. On the other hand, we can see from Plautus that es was the form in use in his day, and we have no reason to suppose that any change had taken place in the time of Cicero and Augustus. Are we then to tell beginners that we do not know the Classical Latin for 'eat that'? Or shall we give them the form which we know to have been in use a few generations earlier? We can at any rate be quite sure that Cicero and his friends would have understood it and accepted it as a Latin word, which is more than we can say of its rival ede.

\section{W. E. P. Pantin.}

1 See Professor Postgate's article "To eat" and "to drink" in Latin, (C.R. XVI. 1902, pp. I IO-I I 5 ). 